\title{
ANALISIS REGRESI LOGISTIK DENGAN METODE PENDUGA BAYES UNTUK MENENTUKAN FAKTOR-FAKTOR YANG MEMPENGARUHI KEJADIAN BAYI BERAT BADAN LAHIR RENDAH
}

\author{
MIRA SERMA TETI, FERRA YANUAR, HAZMIRA YOZZA \\ Program Studi Matematika, \\ Fakultas Matematika dan Ilmu Pengetahuan Alam, Universitas Andalas, \\ Kampus UNAND Limau Manis Padang, Indonesia, \\ mirasermateti27@gmail.com
}

\begin{abstract}
Abstrak. Penelitian ini bertujuan untuk menjelaskan beberapa faktor yang mempengaruhi kejadian bayi berat lahir rendah (BBLR) di Klinik Azimar Anas pada April September 2014. Untuk memenuhi tujuan tersebut akan digunakan metode Regresi Logistik Biner dan metode Bayes. Metode Bayes merupakan salah satu teknik estimasi parameter yang menggabungkan likelihood dan distribusi prior.

Dari penelitian ini diperoleh dua variabel bebas yang berpengaruh nyata terhadap kejadian bayi berat lahir rendah. Variabel tersebut adalah umur Ibu dan paritas. Dengan nilai Odds ratio untuk umur sebesar 0,812 dan paritas sebesar 2,614. Nilai hit ratio keakuratan model peluang logit sebesar $83,33 \%$. Dengan demikian dapat disimpulkan bahwa model peluang logit yang terbentuk sudah layak digunakan untuk mengetahui faktor-faktor yang mempengaruhi kejadian BBLR.
\end{abstract}

Kata Kunci: Regresi logistik biner, metode Bayes, algoritma MCMC, bayi berat lahir rendah

\section{Pendahuluan}

Berat badan merupakan salah satu indikator kesehatan Bayi Baru Lahir (BBL). Secara rata-rata, berat badan bayi lahir yang normal (usia gestasi atau masa kelahiran $37 \mathrm{~s} / \mathrm{d} 41 \mathrm{minggu}$ ) adalah 3200 gram [3]. BBLR (low birth weight infant) adalah bayi dengan berat lahir kurang atau sama dengan 2500 gram tanpa memandang masa gestasi, sebagaimana yang juga dinyatakan WHO ( World Health Organization) sejak tahun 1961. Secara umum, Bayi Berat Lahir Rendah (BBLR) memiliki resiko yang lebih besar untuk mengalami masalah atau komplikasi pada saat lahir. Secara statistik, angka kesakitan dan kematian pada nenonatus (bayi baru lahir yang berusia 28 hari) di negara berkembang adalah tinggi, dengan penyebab utama adalah berkaitan dengan BBLR. Banyak faktor-faktor yang mempengaruhi kejadian BBLR pada penelitian ini akan ditinjau faktor-faktor yang mempengaruhi kejadian BBLR, dan penelitian ini dapat digunakan untuk mengurangi resiko kejadian BBLR.

Pada kasus ini, respon yang dihadapi bersifat biner, yaitu bayi lahir dengan berat normal atau BBLR. Metode regresi klasik yang digunakan untuk memodelkan variabel respon biner ini salah satunya adalah dengan regresi logistik biner. Namun pada artikel ini dalam memodelkan faktor-faktor yang mempengaruhi kejadian 
BBLR tidak menggunakan metode regresi klasik tersebut melainkan dengan metode Bayes. Metode Bayes ini menggunakan fungsi likelihood dan distribusi prior untuk mengestimasi parameter model. Metode Bayes memandang parameter sebagai variabel acak yang menggambarkan pengetahuan awal tentang parameter sebelum pengamatan dilakukan dan dinyatakan dalam suatu distribusi yang disebut dengan distribusi prior. Setelah pengamatan dilakukan, informasi dalam distribusi prior dikombinasikan dengan informasi dengan data sampel melalui teorema Bayes, dan hasilnya dinyatakan dalam bentuk distribusi yang disebut posterior yang selanjutnya menjadi dasar untuk inferensi di dalam metode Bayes [4]. Pada metode Bayes, karena nilai parameternya berasal dari suatu distribusi, maka kesulitan pertama yang dijumpai adalah bagaimana bentuk distribusi parameter tersebut. Estimasi parameter dengan metode Bayes lebih menjanjikan karena tidak perlu diketahui tentang distribusi prior dari populasi, dan sampel yang digunakan dapat berukuran kecil.

\section{Tinjauan Pustaka}

\subsection{Bayi Berat Lahir Rendah}

BBLR adalah bayi yang lahir dengan berat badan kurang dari 2.500 gram pada saat lahir. Banyak faktor yang menyebabkan bayi lahir dengan berat badan kurang. Sebagian faktor berasal dari kondisi yang dialami dari ibu pada masa kehamilan. Faktor-faktor tersebut antara lain penyakit, usia, gizi dan berat badan. Macammacam faktor penyebab BBLR dalam penelitian ini adalah [1]:

(1) Umur ibu.

Usia yang dianggap paling aman mengalami kehamilan dan persalinan adalah 20 - 35 tahun. Persentase tertinggi bayi dengan berat badan lahir rendah terdapat pada ibu dari kelompok remaja dan wanita berusia lebih dari 40 tahun [1].

(2) Paritas.

Paritas adalah jumlah anak yang telah dilahirkan oleh seorang ibu baik lahir hidup maupun lahir meninggal. Paritas yang aman ditinjau dari sudut kematian maternal adalah paritas 1-4 yaitu ibu yang telah melahirkan 1-4 bayi hidup atau lahir meninggal. Ibu dengan paritas 0 (pertama kali hamil) beresiko melahirkan BBLR karena kehamilan pertama sering kali mempengaruhi kondisi kejiwaan serta janin yang dikandungnya. Paritas lebih dari 4 juga beresiko melahirkan BBLR. Suatu kehamilan dapat berpengaruh pada kehamilan berikutnya, karena kondisi kehamilan yang terlalu dekat.

(3) Kehamilan kembar.

Berat badan janin pada kehamilan kembar lebih ringan daripada janin pada kehamilan tunggal pada umur kehamilan sama. Sampai kehamilan 30 minggu kenaikan berat badan janin kembar sama dengan janin kehamilan tunggal. Setelah itu, kenaikan berat badan lebih kecil karena regangan yang berlebihan sehingga menyebabkan peredaran darah plasenta mengurang. Berat badan kedua janin pada kehamilan kembar dapat berbeda antara 50-1000 gram, karena pem- 
bagian daerah plasenta untuk kedua janin tidak sama.

\subsection{Regresi Logistik Biner}

Misalkan ingin dimodelkan hubungan antara beberapa variabel penjelas dengan suatu variabel respon biner, yaitu variabel dikotomi yang hanya mempunyai dua nilai kemungkinan yang biasanya dinyatakan dengan 0 (gagal) dan 1 (sukses).

Dengan analisis regresi hubungan tersebut dapat dinyatakan dalam model :

$$
Y_{i}=\beta_{0}+\beta_{1} X_{i 1}+\beta_{2} X_{i 2}+\cdots+\beta_{k} X_{i k}+\varepsilon_{i}
$$

dengan nilai $Y_{i}=0$ atau $Y_{i}=1$.

Untuk membentuk model regresi logistik biner, maka terlebih dahulu dilakukan transfromasi logit. Misal didefinisikan $\operatorname{logit}\left(p_{i}\right)=\ln \frac{p_{i}}{1-p_{i}}$, maka model dapat dinyatakan sebagai

$$
\operatorname{logit}\left(p_{i}\right)=\beta_{0}+\beta_{1} X_{i 1}+\beta_{2} X_{i 2}+\cdots+\beta_{k} X_{i k}
$$

\subsection{Teorema Bayes}

Jika kejadian kejadian $A_{1}, A_{2}, \cdots, A_{k}$ merupakan sekatan dari ruang contoh $S$ dengan $P\left(A_{i}\right) \neq 0$ untuk $i=1, \cdots, k$, maka untuk sebarang kejadian $B$ yang bersifat $P(B) \neq 0$ berlaku

$$
P\left(A_{j} \mid B\right)=\frac{P\left(A_{j}\right) P\left(B \mid A_{j}\right)}{\sum_{i=1}^{k} P\left(A_{i}\right) P\left(B \mid A_{i}\right)} \propto P\left(A_{j}\right) P\left(B \mid A_{j}\right)
$$

untuk $j=1,2, \cdots, k[2]$.

\subsection{Prior}

Distribusi prior adalah distribusi awal yang memberikan informasi mengenai parameter. Untuk mendapatkan distribusi posterior, terlebih dahulu harus ditentukan distribusi prior dari parameter. Berkaitan dengan penentuan masing-masing parameter, distribusi prior dibagi menjadi dua bagian yaitu [2]:

a. Distribusi prior informatif merupakan distribusi prior yang mengacu pada pemberian nilai parameter dari distribusi prior yang telah dipilih baik distribusi prior konjugat atau tidak. Pemberian nilai parameter pada distribusi prior ini akan sangat mempengaruhi bentuk distribusi posterior yang akan didapatkan pada informasi data yang diperoleh.

b. Distribusi prior non-informatif merupakan pemilihan distribusi priornya tidak didasarkan pada data yang ada.

\subsection{Fungsi Likelihood}

Fungsi kepadatan peluang peubah acak $X_{1}, X_{2}, \cdots, X_{n}$ yang dihitung pada $x_{1}, x_{2}, \cdots, x_{n}$ adalah $f\left(x_{1}, x_{2}, \cdots, x_{n} ; \beta\right)$, dan ini dirujuk oleh fungsi likelihood. 
Untuk $x_{1}, x_{2}, \cdots, x_{n}$ tetap, fungsi likelihood adalah fungsi dari $\beta$ yang dinotasikan dengan $L(\beta)$. Jika $X_{1} X_{2}, \cdots, X_{n}$ merupakan contoh acak dari $f(x ; \beta)$, maka [2]:

$$
\begin{aligned}
\mathrm{E}(\beta) & =f\left(x_{1} ; \beta\right) f\left(x_{2} ; \beta\right) \cdots f\left(x_{n} ; \beta\right) \\
& =\prod_{i=1}^{n} f\left(x_{i} ; \beta\right) .
\end{aligned}
$$

\subsection{Posterior}

Fungsi kepadatan peluang posterior dari $\beta$ jika diketahui contoh pengamatan $x_{1}, x_{2}, \ldots, x_{n}$ adalah [8]:

$$
f(\beta \mid x)=\frac{f\left(x_{1}, x_{2}, \ldots, x_{n} \mid \beta\right) f(\beta)}{\int f\left(x_{1}, x_{2} \ldots, x_{n} \mid \beta\right) f(\beta) \mathrm{d} \beta} \propto f\left(x_{1}, x_{2}, \ldots, x_{n} \mid \beta\right) f(\beta) .
$$

\subsection{Markov Chain Monte Carlo}

Markov Chain Monte Carlo (MCMC) adalah suatu metode untuk menentukan nilai parameter dari suatu integrasi analitik yang sulit. Terdapat tiga macam metode MCMC yang dapat digunakan yaitu metode Metropolis, metode Metropolis-Hasting dan metode Gibbs Sampler. Metode Gibbs Sampler merupakan teknik yang sering dipakai oleh pengguna metode Bayes, termasuk dalam kajian skripsi ini. Metode Gibbs Sampler yang diaplikasikan pada penelitian ini menggunakan software WinBUGS [8]. Algoritma Gibbs Sampler adalah sebagai berikut:

(1) Menentukan nilai awal $\boldsymbol{\beta}^{(0)}$

(2) Untuk iterasi $t=1, \cdots, T$, lakukan persamaan berikut:

- Atur $\boldsymbol{\beta}=\boldsymbol{\beta}^{(t-1)}$

- Untuk $j=0, \cdots, k$ bangkitkan $\beta_{j}$ dari distribusi posterior

- Bangkitkan $\beta_{0}^{(t)}$ dari $f\left(\beta_{0} \mid \beta_{1}^{(t-1)}, \beta_{2}^{(t-1)}, \cdots, \beta_{k}^{(t-1)}, \mathbf{x}\right)$

Bangkitkan $\beta_{1}^{(t)}$ dari $f\left(\beta_{1} \mid \beta_{0}^{(t)}, \beta_{2}^{(t-1)}, \cdots, \beta_{k}^{(t-1)}, \mathbf{x}\right)$

Bangkitkan $\beta_{2}^{(t)}$ dari $f\left(\beta_{2} \mid \beta_{0}^{(t)}, \beta_{1}^{(t)}, \cdots, \beta_{k}^{(t-1)}, \mathbf{x}\right)$

Bangkitkan $\beta_{k}^{(t)}$ dari $f\left(\beta_{k} \mid \beta_{1}^{(t)}, \beta_{2}^{(t)}, \cdots, \beta_{k-1}^{(t)}, \mathbf{x}\right)$

Dari iterasi tersebut dilihat apakah trace plot nya sudah konvergen, bila belum konvergen tambahkan iterasinya sampai konvergen.

\section{Pembahasan}

Data yang digunakan pada penelitian ini adalah data bayi yang lahir di Klinik Bersalin Azimar Anas di Padang pada bulan April - September 2014. Diketahui jumlah ibu melahirkan sebanyak 92 orang. Terdapat 32 orang ibu melahirkan yang tidak memiliki data klinik yang lengkap, sehingga hanya 60 sampel data yang dapat digunakan pada penelitian ini. 


\subsection{Pendugaan Parameter Model}

Pengujian hipotesis terhadap parameter regresi dilakukan dengan uji Wald terhadap masing-masing parameter. Parameter yang signifikan menunjukkan bahwa variabel bebas yang bersesuaian dengan parameter tersebut berpengaruh terhadap respon dan parameter yang tidak signifikan menyatakan variabel bebas tidak berpengaruh terhadap respon. Adapun nilai estimasi parameter dapat dilihat pada Tabel 1.

Tabel 1. Hasil Pengujian Variabel Bebas $\left(\chi^{2}=3,841\right)$

\begin{tabular}{|c|c|c|c|c|c|}
\hline Variabel & Parameter & $\begin{array}{c}\text { Rata- } \\
\text { Rata }\end{array}$ & $\begin{array}{c}\text { Standar } \\
\text { Deviasi }\end{array}$ & $W$ & Kesimpulan \\
\hline Konstanta & $\beta_{0}$ & 3,018 & 1,967 & - & - \\
\hline Umur & $\beta_{1}$ & $-0,211$ & 0,083 & 6,517 & Berpengaruh \\
\hline Paritas & $\beta_{2}$ & 0,887 & 0,423 & 4,403 & Berpengaruh \\
\hline Kembar & $\beta_{3}$ & 1,14 & 1,823 & 0,391 & Tidak Berpengaruh \\
\hline
\end{tabular}

Dari Tabel 1 terlihat bahwa nilai $W$ variabel umur lebih besar dari $\chi^{2}$ tabel $\left(\chi^{2}=3,841\right)$, demikian juga untuk variabel paritas, sedangkan nilai $W$ untuk variabel kejadian kembar lebih kecil dari $\chi^{2}$ tabel. Sehingga dapat disimpulkan bahwa peubah umur dan paritas berpengaruh secara signifikan terhadap BBLR.

Pada analisa sebelumnya diketahui bahwa tidak semua variabel yang dimasukkan ke dalam model signifikan dalam mempengaruhi kejadian BBLR. Oleh karena itu, langkah selanjutnya adalah mengeluarkan variabel tersebut dari model.

Model baru yang diperoleh sebagai berikut:

$$
\operatorname{logit}(\widehat{p})=3,095-0,211 X_{1}+0,874 X_{2}
$$

\subsection{Uji Kekonvergenan Parameter Model}

Langkah selanjutnya dalam metode Bayes adalah melakukan uji kekonvergenan dari parameter model yang telah diestimasi nilainya. Uji ini dilakukan dengan mengamati hasil yang ditampilkan oleh trace plot.

Berdasarkan gambar yang diperoleh diatas, dapat disimpulkan bahwa asumsi kekonvergenan terpenuhi karena sebaran data telah stabil yang terletak diantara dua garis horizontal yang paralel.

Selanjutnya akan ditampilkan bentuk fungsi kepadatan peluang untuk setiap estimasi parameter model yang diperoleh dari proses gibbs sampler. Fungsi kepadatan peluang tersebut disajikan pada Gambar 2. Adapun selang kepercayaan 95\% untuk setiap estimasi parameter disajikan pada Tabel 2.

Berdasarkan Tabel 2 diperoleh bahwa selang kepercayaan 95\% untuk estimasi $\beta_{1}$ adalah $(-0.387,-0.063)$, estimasi $\beta_{2}$ adalah $(0.097,1,714)$, dan untuk estimasi $\beta_{0}$ diperoleh $(-0.587,7.163)$. 

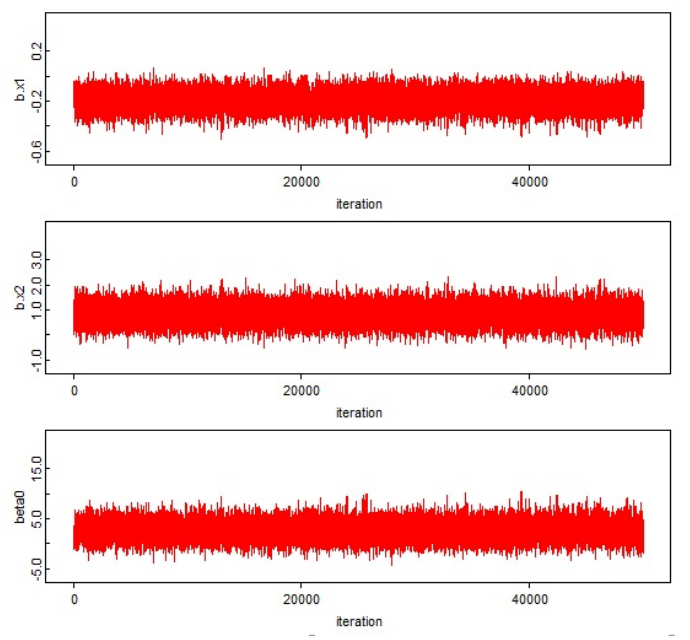

Gambar 1. History Trace Plot
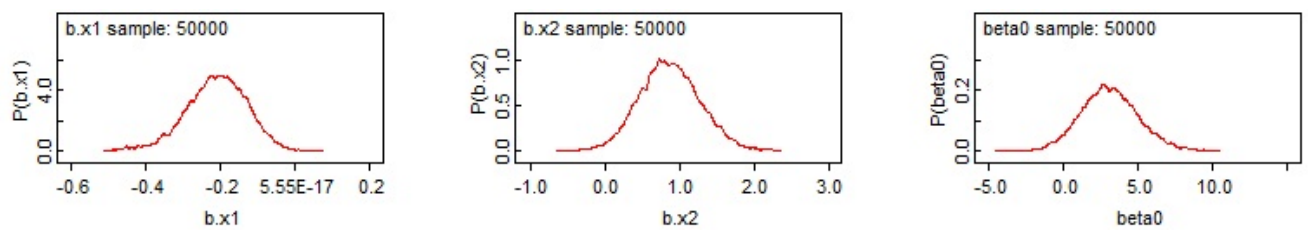

Gambar 2. Fungsi Kepadatan Parameter Dugaan

Tabel 2. Selang Kepercayaan 95\% dari parameter

\begin{tabular}{|c|c|c|c|c|}
\hline Parameter & $\begin{array}{c}\text { Rata- } \\
\text { Rata }\end{array}$ & $\begin{array}{c}\text { standar } \\
\text { Deviasi }\end{array}$ & $\begin{array}{c}\text { Batas } \\
\text { Bawah (2,5\%) }\end{array}$ & $\begin{array}{c}\text { Batas } \\
\text { Atas (97,5\%) }\end{array}$ \\
\hline$\beta_{0}$ & 3,095 & 1,951 & $-0,587$ & 7,163 \\
\hline$\beta_{1}$ & $-0,211$ & 0,082 & $-0,387$ & $-0,063$ \\
\hline$\beta_{2}$ & 0,874 & 0,412 & 0,097 & 1,714 \\
\hline
\end{tabular}

\subsection{Interpretasi Koefisien}

Untuk menginterpretasikan seberapa besar pengaruh umur ibu dan paritas terhadap kondisi bayi berat lahir rendah digunakan nilai odds ratio yang nilainya diperlihatkan pada Tabel 3 berikut.

Pada Tabel 3 dapat dilihat nilai Odds Ratio untuk umur yaitu 0,812 artinya setiap kenaikan 1 tahun umur Ibu, maka resiko untuk kelahiran dengan BBLR akan cenderung lebih rendah untuk mengalami kejadian BBLR sebesar 0,812 kali. Hasil ini agak bertentangan dengan teori-teori terkait faktor-faktor yang mempengaruhi BBLR. Hal ini dapat diterima karena data kajian ini yang diambil dari Klinik Azimar Anas Padang yang melibatkan 60 orang responden diketahui bahwa umur 
Tabel 3. Nilai Odds Ratio Model Regresi Logistik

\begin{tabular}{|c|c|}
\hline Peubah bebas & $\operatorname{Exp}(\beta)$ \\
\hline Umur $\left(X_{1}\right)$ & 0,812 \\
\hline Paritas $\left(X_{2}\right)$ & 2,614 \\
\hline
\end{tabular}

Ibu yang mengalami BBLR cenderung terjadi pada umur rendah dan Ibu yang mengalami BBLN justru terjadi pada umur tinggi.

Nilai Odds Ratio untuk paritas yaitu 2,614 artinya setiap bertambah 1 paritas memiliki resiko lebih besar untuk mengalami kejadian BBLR sebesar 2,614 kali. Hal ini menginformasikan bahwa semakin sering seorang Ibu melahirkan akan meningkatkan resiko Ibu tersebut mengalami BBLR.

\subsection{Keakuratan Model}

Layak atau tidak suatu model regresi dapat dilihat dari pengelompokkan objek yang benar. Pengelompokkan didasarkan pada nilai resiko logitnya yaitu:

$$
\widehat{p}_{i}=\frac{\exp \left(3,095-0,211 X_{1}+0,874 X_{2}\right)}{1+\exp \left(3,095-0,211 X_{1}+0,874 X_{2}\right)}
$$

Jika nilai $\widehat{p}_{i}$ lebih besar 0,5 maka responden dikelompokkan mengalami kejadian BBLR, sedangkan jika $\widehat{p}_{i}$ kecil atau sama dengan 0,5 maka responden dikelompokkan tidak mengalami kejadian BBLR.

Berdasarkan resiko logit yang diperoleh terdapat 10 responden yang tidak mengalami kejadian BBLR, sedangkan pada kenyataanya responden tersebut mengalami kejadian BBLR. Nilai keakuratan model dalam menjelaskan kejadian BBLR yang dapat dihitung sebagai berikut:

$$
\begin{aligned}
\text { hit ratio } & =\frac{\text { banyak objek yang diklasifikasi dengan benar }}{\text { total banyak pengamatan }} \times 100 \% \\
& =\frac{50}{60} \times 100 \% \\
& =83,33 \%
\end{aligned}
$$

Berdasarkan nilai hit ratio di atas, model tersebut memberikan keakuratan model sebesar $83,33 \%$. Dengan demikian dapat disimpulkan bahwa model logit yang terbentuk sudah layak digunakan untuk mengetahui faktor-faktor yang mempengaruhi kejadian BBLR.

\section{Kesimpulan}

Berdasarkan tiga variabel bebas yang diasumsikan merupakan faktor-faktor yang mempengaruhi bayi berat lahir rendah, diperoleh dua variabel bebas yang berpengaruh nyata terhadap kondisi bayi berat lahir rendah. Faktor-faktor tersebut adalah umur ibu dan paritas. 
Berdasarkan uji kekonvergenan parameter model yang dilihat dari trace plot yang konvergen, hal tersebut sudah memenuhi asumsi kekonvergenan karena telah menyebar stabil di sekitar dua garis horizontal yang paralel.

Nilai Odds Ratio untuk umur yaitu 0,812 artinya setiap kenaikan 1 tahun umur memiliki resiko lebih rendah untuk mengalami kejadian BBLR sebesar 0,812 kali. Nilai Odds Ratio untuk paritas yaitu 2,614 artinya setiap bertambah 1 paritas memiliki resiko lebih besar untuk mengalami kejadian BBLR sebesar 2,614 kali berarti semakin sering Ibu melahirkan maka resiko melahirkan BBLR lebih tinggi.

Berdasarkan nilai hit ratio, keakuratan model peluang logit sebesar $83,33 \%$. Dengan demikian dapat disimpulkan bahwa model peluang logit yang terbentuk sudah layak digunakan untuk mengetahui faktor-faktor yang mempengaruhi kejadian BBLR.

\section{Ucapan Terima kasih}

Penulis mengucapkan terima kasih kepada Bapak Yudiantri Asdi, M.Sc, Ibu Izzati Rahmi HG, M.Si dan Ibu Dr. Maiyastri yang telah memberikan masukan dan saran sehingga paper ini dapat diselesaikan dengan baik.

\section{Daftar Pustaka}

[1] Alya, D. 2014. Faktor-faktor yang berhubungan dengan Bayi Berat Lahir Rendah (BBLR) di Rumah Sakit Ibu dan Anak Banda Aceh Tahun 2013. Skripsi. Program Studi Diploma IV Kebidanan STIKes Ubudiyah: Banda Aceh.

[2] Bain, L.J dan Engelhardt, M. 1992. Introduction to Probability and Mathematical Statistics Second Edition. Duxbury Press: California.

[3] Barkat, I. 2013. Mengenal Bayi Berat Lahir Rendah. http://muslimhusada. blogspot.com/ 2013/05/ berat-bayi-lahir-rendah-makalah-artikel.html. Diakses pada 31 Desember 2014, 20:30.

[4] Berger, C. 1990 Statistical Inference. Pasific Grove : New York.

[5] Bolstad, W.M. 2007 Introduction to Bayesian Statistics Second Edition. A John Wiley \& Sons. Inc; America.

[6] Draper, N dan H. Smith. 1992. Analisis Regresi Terapan Edisi Kedua. PT. Gramedia Pustaka Utama, Jakarta.

[7] Kleinbaum, D.G. dan Klein, M. 2002. Logistic Regression A Self Learning Text Second Edition. Springer : New York.

[8] Ntzoufras, I. 2009. Bayesian Modeling Using WinBUGS. John Wiley \& Sons, Inc: Ney Jersey.

[9] Walpole, R.E. 1993. Pengantar Statistika Edisi ke-3. PT Gramedia Pustaka Utama: Jakarta. 